\title{
Babinski, Bektherev, Cerletti, Head, and Hitzig: European Neurologists Nominated for the Nobel Prize 1901-1950
}

\author{
Nils Hansson ${ }^{a}$ Lotte Palmen ${ }^{a} \quad G^{2}$ iacomo Padrini ${ }^{a} \quad$ Axel Karenberg ${ }^{b}$ \\ aDepartment for the History, Philosophy and Ethics of Medicine, Faculty of Medicine, Heinrich-Heine-University, \\ Düsseldorf, Germany; ${ }^{\text {b }}$ nstitute for the History of Medicine and Medical Ethics, Faculty of Medicine, University of \\ Cologne and University Hospital Cologne, Cologne, Germany
}

\section{Keywords}

Nobel prize · Excellence in neurology · Joseph Babinski .

Henry Head · Ugo Cerletti

\begin{abstract}
Introduction: This article provides for the first time an overview of the most often nominated European neurologists for the Nobel Prize, who never received the award. It sheds light on candidates from France, Germany, Italy, Russia, and the UK during the first half of the 20th century. The aim is to highlight the candidates in the field of neurology, to discuss key arguments in the nomination letters, and to raise questions about research trends and hotspots in European neurology 1901-1950. Methods: Using the Nobel nomination database which contains $>5,000$ nominations in the prize category physiology or medicine from 1901 to the early 1950s, we listed European neurologists who were nominated more than once during this time period. We then collected nomination letters and jury reports of the prime candidates in the archive of the Nobel Committee for physiology or medicine in Sweden to explore nomination networks and motives. Results: We pinpointed scholars like Joseph Babinski, Vladimir Bektherev, Sir Henry Head, Eduard Hitzig, and Ugo Cerletti. The
\end{abstract}

karger@karger.com

(c) 2020 S. Karger AG, Basel

www.karger.com/ene

Karger ${ }^{\prime \prime}=$ nomination motives were diverse, ranging from "lifetime" achievements and textbooks to singular (eponymous) discoveries. Issues of scientific priority disputes were central in most nomination letters. Conclusion: Nobel Prize nominations constitute a lens through which credit and recognition around major contributions in neurology during the 20th century can be examined. They are unique sources that enable the reconstruction of both research trends in the field and the reputation of individual neurologists.

(c) 2020 S. Karger AG, Basel

\section{Introduction}

No other award has such a strong aura of scientific excellence as the Nobel Prize. Thus, it is not surprising that much historical research has illuminated various aspects around the prize and its 5 original categories physics, chemistry, physiology or medicine, literature, and peace [1-5]. This article does not focus on the laureates, but on the "unsung heroes," that is, candidates who were nominated more than once for the award, but never received it. Such an alternative approach has proven fruitful in studies about Nobel Prize nominations of physicians in 
different fields, for example, in surgery [6], cardiology [7], pharmacology [8], and psychiatry [9] to investigate mechanisms of reputation and credit in medicine. The article aims at pinpointing nominated neurologists for the Nobel Prize during the first half of the 20th century from (in alphabetical order) France, Germany, Italy, Russia, and the UK - 5 of the leading European countries in this respect during the time period [10-16]. Which were "the favourite sons" [17] among the nominees in each country, and how were they portrayed in the nomination letters? Which were the key arguments? Why were the achievements of the candidates not deemed as the "greatest benefit to mankind" as the Swedish inventor Alfred Nobel (1833-1896) stipulated in his will of 1895? And what do the Nobel dossiers say about research trends in neurology 1901-1950?

Neurology and neuroscience have since the first Nobel Prize selection process in 1901 been of particular interest to the prize jury, officially named the Nobel Committee for physiology or medicine, based at the Karolinska Institute in Solna, Sweden. Commentators have suggested that around 20 Nobel Prizes have been awarded to neuroscientists, from Camillo Golgi's (1843-1926) and Santiago Ramón y Cajal's (1852-1934) award in 1906 "in recognition of their work on the structure of the nervous system" [18] to John O'Keefe, May-Britt Moser, and Edvard I. Moser in 2014 "for their discoveries of cells that constitute a positioning system in the brain" [19-21]. The number is impressively high when compared to the corresponding number in other fields such as surgery: not more than 4 times has the prize jury so far honored scholars for a surgical achievement [22]. One explanation is that the lion's share of the Nobel Committee members has been basic scientists. However, not least since the prize-winning work of several of the neuroscientist-laureates has been interdisciplinary, it is a delicate task to define laureate disciplines in retrospect. In this study, we have included scholars who described themselves as neurologists or worked in a department for neurology. It should be noted that neurology was a young discipline at the turn of the 20th century: The Society of German Neurologists, for instance, was founded in 1907 [23].

The most in-depth account about neuroscientists in this context was written by Göran Liljestrand (18861968), secretary of the Nobel Committee for physiology or medicine for 4 decades, who summarized key Nobel neuroscientists [24]. His focus was on the Nobel laureates from 1901 to 1950, but he also mentioned some "unsuccessful” candidates such as Oscar Vogt (1870-1959), Cécile Vogt (1875-1962), Louis Édouard Lapicque (1866-

European Neurologists Nominated for the Nobel Prize
1952), and John Newport Langley (1852-1925). Impressed by Langley's research, Liljestrand noted: “Our knowledge of the autonomic nervous system is largely based on the investigations of J.N. Langley" [25]. He revealed that all prize jury members recognized the importance of Langley's work, with 1 exception: Frithiof Lennmalm (1858-1924), Professor of Neuropathology at the Karolinska Institute and a member of the Nobel Committee 1908-1910 and 1917-1920, was not convinced. That single negative votes can be enough to put a spoke in the selection process wheel has been demonstrated in the studies of Nobel Prize files regarding neurosurgeons such as Harvey Cushing (1869-1939) [26].

\section{Materials and Methods}

Drawing on the Nobel nomination database (nobelprize.org) which contains $>5,000$ nominations in the category physiology or medicine from 1901 to 1953, we listed repeatedly nominated European neurologists during the first 5 decades of the 20th century. We then collected nomination letters of the key candidates (written in English, French, German, Italian, and Swedish) in the archive of the Nobel Committee for physiology or medicine. The archive keeps the nomination dossiers and committee evaluations of all proposed scholars. Only invited scholars by the Nobel Committee can submit eligible nomination letters, but professors at medical faculties in Scandinavia and previous Nobel laureates (physiology or medicine) may propose candidates each year. According to the Nobel statutes, there is an embargo of 50 years before historians can view the files.

\section{Results}

In the following, we will highlight single Nobel candidates in the field of neurology to pinpoint arguments in favor of the nominees as well as rejection reasons by the Nobel Committee.

\section{France}

Primarily due to Babinski's sign and other associated eponyms such as the Anton-Babinski syndrome and the Babinski-Nageotte syndrome, the French-Polish neurologist Joseph Babinski (1857-1932) is still known around the globe [27]. In his heydays as professor in Paris, he was nominated by 14 scholars for the Nobel Prize (Table 1). Hence, Babinski had a fairly strong support by nominators based in several European countries. The first nomination was submitted by the Russian professor Leon Popielski (1866$1920)$ in 1914. In 12 pages, written in German, the major scientific language in northern Europe in general and Swe-

Eur Neurol 2020;83:542-549 
Table 1. Nominees from France 1901-1950

\begin{tabular}{lll}
\hline Year(s) & Nominee & Motives \\
\hline $\begin{array}{ll}1914-1932, \\
14 \text { nominations }\end{array}$ & Joseph Babinski & $\begin{array}{l}\text { Work on reflexes, the differential diagnosis between organic diseases and hysteria, and the } \\
\text { symptomatology of diseases in the cerebellum and the medulla oblongata }\end{array}$ \\
\hline $\begin{array}{l}1921, \\
2 \text { nominations }\end{array}$ & Pierre Marie & Work on acromegalia and on numerous nervous diseases \\
\hline
\end{tabular}

Table 2. Nominees from Germany 1901-1950

\begin{tabular}{|c|c|c|}
\hline Year(s) of nomination & Nominee & Motive(s) \\
\hline $\begin{array}{l}1926-1937 \\
17 \text { nominations }\end{array}$ & Otfrid Foerster & $\begin{array}{l}\text { Clinical research in neurology, especially on the subjects of sensation and epilepsy, work } \\
\text { on neurosurgery and the physiology of the nervous system, especially the anatomy and } \\
\text { physiology of peripheral nerves, work on neurology, traumatic injuries of the spinal } \\
\text { marrow and the sensation of pain; the anatomy, physiology, and damage of the } \\
\text { peripheral nerves }\end{array}$ \\
\hline $\begin{array}{l}1909-1922, \\
17 \text { nominations }\end{array}$ & Heinrich Quincke & Work on lumbar puncture \\
\hline $\begin{array}{l}1910, \\
3 \text { nominations }\end{array}$ & Ludwig Edinger & Work on brain development \\
\hline $\begin{array}{l}1922-1950, \\
9 \text { nominations }\end{array}$ & Cécile Vogt & $\begin{array}{l}\text { Work on the architectonics of the cerebral cortex, cortex localization, and the function } \\
\text { of corpus striatum and research on the physio-pathoarchitectonics of the brain }\end{array}$ \\
\hline $\begin{array}{l}1940-1950, \\
6 \text { nominations }\end{array}$ & Hans Berger & Development of and work on the electroencephalograph \\
\hline $\begin{array}{l}\text { 1914-1919, } \\
2 \text { nominations }\end{array}$ & Franz Nissl & $\begin{array}{l}\text { Work on the nervous system and a method to investigate the same and work on mental } \\
\text { illness }\end{array}$ \\
\hline $\begin{array}{l}1923-1924, \\
2 \text { nominations }\end{array}$ & Paul Flechsig & Investigations on the neural conduction paths in the brain and spinal cord \\
\hline $\begin{array}{l}1910-1914, \\
2 \text { nominations }\end{array}$ & Wilhelm Erb & Work on electrodiagnostics and neuropathology \\
\hline
\end{tabular}

den in particular at that time $[28,29]$, Popielski characterized Babinski as "the greatest master" in neurology [30]. He argued that Babinski had developed new technical methods to examine patients and illuminated new symptoms and syndromes "in a very original manner." Starting with his influential work on reflexes including the toe phenomenon that Babinski described in the 1890s, Popielski elaborated on several of Babinski's research interests, including syphilis, hysteria, and neurosurgery. For each of them, he provided references and quotes in textbooks and scientific lit- erature and discussed potential "competitors." For example, he underlined that Babinski had published on syphilis prior to the German neurologist Wilhelm Heinrich Erb (1840-1921). However, in the end, the large number of arguments was probably counterproductive: The Nobel Committee was and still is more interested in single great discoveries than all-round research. Other nominators portrayed Babinski first and foremost as a semiologist with a focus on his work on reflexes as a diagnostic aid, but they could also not convince the committee members. 
Table 3. Nominees from Italy 1901-1950

\begin{tabular}{lll}
\hline Year & Nominee & Motive \\
\hline $\begin{array}{ll}1920-1926, \\
7 \text { nominations }\end{array}$ & Leonardo Bianchi & $\begin{array}{l}\text { Work on the physiology and pathology of the brain and work } \\
\text { from 1919, "La Meccanica del Cervello" }\end{array}$ \\
\hline $\begin{array}{l}1943-1950, \\
24 \text { nominations }\end{array}$ & Ugo Cerletti & Electroshock treatment of psychoses \\
\hline $\begin{array}{l}1948-1950, \\
4 \text { nominations }\end{array}$ & Lucio Bini & Electroshock treatment of psychoses \\
\hline
\end{tabular}

Among other nominated French neurologists, the Parisian professor Pierre Marie (1853-1940) stands out [31]. The former student of Paul Broca (1824-1880) and Jean-Martin Charcot (1825-1893) was put forward twice in 1921 by 2 Italian professors who emphasized his work on acromegalia. In contrast to Babinski, Marie published a comprehensive textbook, but that fact did not increase his chances for a Nobel Prize.

\section{Germany}

The German psychiatrist and neurologist Eduard Hitzig (1838-1907) of Berlin was nominated 5 times between 1904 and 1905 for the Nobel Prize in physiology or medicine (Table 2) [32]. Having held positions in $\mathrm{Zu}-$ rich and Halle, he is, together with the anatomist Gustav Fritsch (1838-1927), remembered for work concerning the function of the brain, particularly electrophysiology, showing that different parts of the body are represented by specific areas in the cortex [33]. Among his nominators, we found only German physicians and scientists, such as the otologist August Lucae (1835-1911), the internist Hermann Eichhorst (1849-1921), and the zoologist and anatomist Adolph von La Valette-St. George (1831-1910). Looking at the motives for the nominations, Hitzig's "Work on the excitation of the brain cortex and the foundation of the localization" and more in general his "innovative new research on the brain" were the main motives. This work had according to nominators influenced neighboring disciplines. "The discovery has made it possible for neurosurgeons to save thousands of lives" [34]. Characteristic for the rhetoric in Nobel nominations [35], they also argued that his work will have a lasting impact: "the man and his discovery will for all future remain a milestone in medicine" [36]. Why were the nominations not successful? In this particular case, there seems to be a clear-cut answer. Liljestrand, the previously mentioned former secretary of the Nobel Committee argued that Hitzig's work (first published in
1870) was carried out too long ago: "[By the time of nomination], the discovery was too old for special investigation" [37].

\section{Italy}

From 1901 to 1950, the Italian neurologist Ugo Cerletti (1877-1963) was nominated $>20$ times for work on electroconvulsive therapy, which he with colleagues like the psychiatrist Lucio Bini (1908-1964) had developed for patients suffering from schizophrenia, psychosis, and dementia (Table 3) $[38,39]$. While the majority of the nominators were Italian colleagues, 7 foreign scholars proposed Cerletti during the examined time period. His supporters viewed the method as a breakthrough. Nominator Giorgio Benassi argued that the therapy could heal asthma and certain skin diseases, and Robert Foster Kennedy (1884-1952) referred to the treatment in a nomination letter as a "first step in the conquest of the psychoses" and, in characteristic hyperbole Nobel nomination style, compared it with other milestones in the history of medicine: "It is as important a happening in Psychiatry as was Lister's first carbolic spray in surgery" [40].

Even though the nominators were convinced of Cerletti's method, some also pointed at scientific priority disputes and critical remarks in the scientific community. Kennedy, again, stated that "the merit of introducing convulsions for the treatment of mental illness originally goes to L[adislas] Meduna," who had induced the seizures chemically. In addition, he mentioned that followers of Sigmund Freud's (1856-1939) school firmly opposed the therapy [40]. Nobel Committee secretary Göran Liljestrand acknowledged that "the shock treatment has been widely used [...] [and] that in some areas [...] considerable improvements have been made" [41]. In the end, however, the committee remained hesitant and argued that more clinical data should be analyzed before the real practical value could be determined. Interestingly, the debate on this controversial therapy is ongoing [42]. 
Table 4. Nominees from Russia 1901-1950

\begin{tabular}{lll}
\hline Year & Nominee & Motive \\
\hline $\begin{array}{l}1912-1925, \\
10 \text { nominations }\end{array}$ & Vladimir Bekhterev & $\begin{array}{l}\text { Work on the anatomy and pathology of the nervous system and } \\
\text { various discoveries concerning the anatomy of the nervous system, } \\
\text { especially studies of reflexes }\end{array}$ \\
$\begin{array}{ll}1934-1935, \\
4 \text { nominations }\end{array}$ & Leon A. Orbeli & $\begin{array}{l}\text { Work on the role of the sympathetic nervous system in the animal } \\
\text { organism }\end{array}$ \\
\hline
\end{tabular}

Table 5. Nominees from UK 1901-1950

\begin{tabular}{lll}
\hline Year & Nominee & Motive \\
\hline $\begin{array}{l}\text { 1901-1921, } \\
\text { nominations }\end{array}$ & Henry Head & $\begin{array}{l}\text { Researches on the sensory functions of the nervous system, } \\
\text { particularly those of the cerebral cortex }\end{array}$ \\
\hline $\begin{array}{l}1901-1925, \\
17 \text { nominations }\end{array}$ & John Langley & Work on the autonomous nervous system \\
\hline $\begin{array}{l}\text { 1904-1912, } \\
\text { nominations }\end{array}$ & William R. Gowers & His publication: "Manual of diseases of the nervous system" \\
\hline
\end{tabular}

Another Italian candidate was the neuropathologist Leonardo Bianchi (1848-1927) [43]. Nominated 7 times from 1920 to 1922, he was appraised for work on the function of the frontal lobe as well as for his research on the physiology of the brain.

\section{Russia}

The sociologist Harriet Zuckerman has noted that the "Nobel population" (laureates and nominees) constitute an ultra-elite in science and medicine [1]. That the members of this "Champions League" often have social and scientific ties to each other is true also for the Russian neurologist Vladimir Bekhterev (1857-1927), the most often nominated neurologist from Russia/Soviet Union during the first half of the 20th century (Table 4). His network included rivals like the 1904 Nobel laureate Ivan Pavlov (1849-1936) and collaborators like the Nobel nominees Wilhelm Wundt (1832-1920), Paul Flechsig (1847-1929), and Alexandre Dogiel (1852-1922). Next to his studies in neurology, anatomy, physiology, and psychiatry, Bekhterev was also praised for founding the psychoneurological institute in St Petersburg: "The institute is so well-known, that no further elaboration is necessary" [44]. As part of Russian reflexology, Bekhterev's legacy consists mainly of his contributions to neuroanatomy, the construction of new syndromes and diseases, and his biopsychosocial model of disease in general anticipating much later research trends $[45,46]$. Although the scientific community around the world recognized his accomplishments, the immediate effect was probably more national than global. As one of his disciples put it: "Whereas neurology on the whole owes Bekhterev immensely important and substantial discoveries that further its development, Russian neurology in particular owes Vladimir Mikhailovich its existence" [47].

\section{United Kingdom}

"Table 5" (Sir Henry Head, Credit: Wellcome Collection, Library No. 12884i).

The English neurologist Henry Head (1861-1940) was nominated already for the first Nobel Prize in 1901, praised for research on herpes zoster and investigations in relation to human sensation (Fig. 1). All in all, he was nominated 5 times until 1921, twice by the UCL Professor of anatomy G. Elliot Smith (1871-1937). Elliot put forward Head's "remarkable researches on the sensory functions of the nervous system during the last 26 years" (1919) that he was the editor of the journal "Brain" (1921), and he also emphasized very recent work: "[Head's] epoch-making researches on the sensory functions of the cerebral cortex, which were published this week (Brain) [...] In my opinion this is perhaps the greatest contribution to the borderline regions between physiology and psychology which has yet been made." In fact, Head 


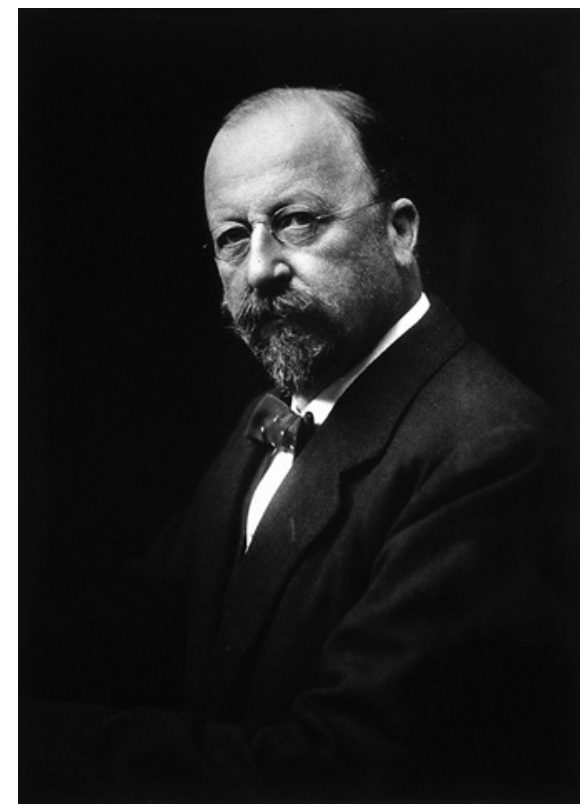

Fig. 1. Sir Henry Head, credit: Wellcome Collection, attribution 4.0 International (CC BY 4.0).

reached the Nobel Committee shortlist along with 9 other scholars in 1919 and with 18 researchers in 1920. In the end, Jules Bordet (1870-1961) received the award in 1919 "for his discoveries relating to immunity," and in 1920, the committee honored August Krogh (1874-1949) "for his discovery of the capillary motor regulating mechanism."

Thus, both "epoch-making" research and gate-keeper positions were brought up to underline Head's reputation. Other manifestations of excellence for neurologists such as membership in prestigious societies, international acclaim, and eponymous discoveries were mentioned in the nomination for the English neurologist John Hughlings Jackson (1835-1911) for the 1910 Nobel Prize, submitted by J.M. Sandwith:

"I have the honour to propose as a candidate for the prize in the section of Physiology and Medicine, the name of J. H u gh $\mathrm{l}$ in g s J a ck s o n [...] M. D. St. Andrews, Hon. M.D. Bologna, F.R.C.P. London, Hon. F.R.C.P.I. Fellow of the Royal Society, Corresponding Member Roy. Acad. Med. of Belgium, Consulting Physician to the London Hosp. and to the Hosp. for Epilepsy and Paralysis. His great work has been, from the study of Jacksonian Epilepsy and the lesions in diseases of the brain, to determine the relation of different parts of the cortex of the brain to the movement of the different parts of the body - discoveries which were afterwards confirmed by the experimental work of Fritsch, Hitzig, Ferrier and others. [...] His writings are scattered through medical literature and are well known to all neurologists in Europe and the United States" [48].

\section{Conclusion}

As this overview shows, European neurologists were portrayed in Nobel Prize nominations as scholars who had made a lasting impact in the discipline and beyond. Apart from the French neurologist Cécile Vogt, nominated for work on the architectonics of the cerebral cortex and the first female scholar to be proposed for a Nobel Prize in physiology or medicine $[49,50]$, all of the nominees were men. Unsurprisingly, several of the nominators were neuroscientists, including Theodor Ziehen (18621950), one of the founders of this journal, who (successfully) proposed Santiago Ramón y Cajal in 1906. Just as the motives for nomination were manifold, the Nobel Committee protocols show various reasons to reject the proposals. Next to scientific priority disputes which were central in most discussions, some work was judged too old (Hitzig), too controversial (Cerletti), or the discovery in question was described "merely a diagnostic aid" (Babinski). Nominators emphasizing that scholars had gained a strong reputation in the scientific community for founding an institute (Bektherev) or earned gatekeeper position as journal editors (Head) also did not convince the prize jury. We did not find any political remarks, for example, comments about political activities or research circumstances in Nazi Germany or in Fascist Italy in the Nobel Committee evaluations about the mentioned neurologists.

The relatively large number of German candidates reflects the interest of these researchers in neurology and the neurosciences, but it may also be due to the decentralized structure of German science with its numerous rival universities. In addition, the majority of the German nominees had passed their formative years during the Wilhelmine era (1890-1918), only few during the Weimar Republic (1919-1933).

The activities and interests of the nominees presented in this article reflect most of the neurological research trends in the first half of the 20th century. In the basic sciences, they range from architectonics of the developing/ normal/abnormal brain to physiological issues linked to the somatic and autonomic nervous system, in clinical neurology from "hands-on" and technical diagnostics to 
new conceptualizations of diseases. The mere description of findings, either morphological or clinical, was paramount. Except for the controversial electroshock treatment and the equally contentious epilepsy surgery, few research activities had a direct therapeutic impact and, thus, no immediate benefit for neurological patients. In conclusion, Nobel Prize nominations and jury evaluations constitute a lens through which credit and recognition around major contributions in neurology during the 20th century can be examined.

\section{Acknowledgement}

Files on neurologists were kindly provided by the Nobel Committee for Physiology or Medicine, Medicinska Nobelinstitutet, Solna, Sweden. All translations from French, German, Italian, and Swedish into English were done by the authors.

\section{Statement of Ethics}

No ethics approval was required.

\section{Conflict of Interest Statement}

The authors have no conflicts of interest to declare.

\section{Funding Sources}

The authors did not receive any funding.

\section{Author Contributions}

N.H. designed the research. All authors contributed to the analysis and drafting of the manuscript. All authors approved the manuscript.

\section{References}

1 Zuckerman H. Scientific elite. Nobel laureates in the United States. London: MacMillan; 1977.

2 Friedman RM. The politics of excellence: behind the Nobel Prize in science. New York: Freeman \& Times Books; 2001.

3 English JF. The economy of prestige: prizes, awards, and the circulation of cultural value. Cambridge: Harvard University Press; 2008.

4 Widmalm S, editor. Special issue: the Nobel Prizes and the Public image of science. Public Underst Sci. 2018;27(4).

5 Hansson N, Halling T, Fangerau H, editors Attributing excellence in medicine: the history of the Nobel Prize. Leiden: Brill; 2019.

6 Hansson N, Jones DS, Schlich T. Defining 'cutting-edge' excellence: awarding Nobel Prizes (or not) to surgeons. In: Hansson N, Halling T, Fangerau H, editors. Attributing excellence in medicine: the history of the Nobel Prize. Leiden: Brill; 2019. p. 122-39.

7 Drobietz M, Moll F, Hansson N. "Ein vornehmer und nobler Charakter": Die Nobelpreisnominierungen für Hugo W. Knipping. Der Kardiologe 2020 (online first). doi.org/10. 1007/s12181-019-00371-2.

8 Pohar M, Hansson N. The "Nobel Population" in pharmacology: Nobel Prize laureates, nominees and nominators 1901-1953 with a focus on B. Naunyn and O. Schmiedeberg. Naunyn Schmiedebergs Arch Pharmacol. 2020;393:1173-85.

9 Hansson N, Halling T, Fangerau H. Psychiatry and the Nobel Prize: Emil Kraepelin's nobelibility. Trames. 2016;4:393-401.
10 Clarac F, Boller F. History of neurology in France. In: Finger, S, Boller F, Tyler KT, editors. History of neurology. Edinburgh: Elsevier; 2010. Vol. 95; p. 629-56.

11 Isler H. Neurology and the neurological sciences in the German-speaking countries. In: Finger, S, Boller F, Tyler KT, editors. History of neurology. Edinburgh: Elsevier; 2010. Vol. 95; p. 667-90.

12 Martin M, Karenberg A, Fangerau H. Neurologie und Neurologen in der NS-Zeit: Voraussetzungen und Rahmenbedingungen vor und nach 1933. Nervenarz. 2016;87:5-17.

13 Pantel J. Streitfall Nervenheilkunde: eine Studie zur disziplinären Genese der klinischen Neurologie in Deutschland. Fortschr Neurol Psychiatr. 1993;61:144-1563.

14 Bentivoglio M, Mazzarello P. History of neurology in Italy. In: Finger S, Boller F, Tyler KT, editors. History of neurology. Edinburgh: Elsevier; 2010. Vol. 95; p. 719-36.

15 Lichterman B. A history of Russian and Soviet neuro(patho)logy. In: Finger S, Boller F, Tyler KT, editors. History of neurology. Edinburgh: Elsevier; 2010. Vol. 95; p. 737-54.

16 Rose FC. An historical overview of British neurology. In: Finger S, Boller F, Tyler KT, editors. History of neurology. Edinburgh: Elsevier; 2010. Vol. 95; p. 613-28.

17 Crawford E. Internationalism in science as a casualty of the First World War: relations between German and Allied scientists as reflected in nominations for the Nobel prizes in physics and chemistry. Soc Sci Inf. 1988;27: 163-201.
18 Mazzarello P. The hidden structure. A scientific biography of Camillo Golgi. Oxford: Oxford University Press; 1999.

19 Available from: https://faculty.washington. edu/chudler/nobel.html [cited 2020 May 5].

20 Available from: https://www.nobelprizemedicine.org/selecting-laureates/history/the-nobel-prizes-in-the-field-of-neuroscience/ [cited 2020 May 5].

21 Sourkes TL. Introduction: neuroscience in the nobel perspective. J Hist Neurosci. 2006; 15(4):306-17.

22 Hansson N. Excellence in orthopaedic surgery: an overview of Nobel Prize nominees 1901-1960 with focus on Friedrich Pauwels and Gerhard Küntscher. Int Orthop. 2018;42: 2957-60.

23 Karenberg A, Fangerau H, Steinmetz H, Berlit P, Grond M. Historical review: a short history of German neurology: from its origins to the 1940s. Neurol Res Pract. 2019;1(1).

24 Liljestrand G. The prize in physiology or medicine. In: Schück H, Sohlman R, Österling A, Liljestrand G, Westgren A, Siegbahn M, editors, et al. Nobel: the man and his prizes. New York, NY: Elsevier; 1962. p. 299-331.

25 Liljestrand G. The prize in physiology or medicine. In: Schück H, Sohlman R, Österling A, Liljestrand G, Westgren A, Siegbahn M, editors. Nobel: the man and his prizes. New York, NY: Elsevier; 1962. p. 299-331, 315.

26 Hansson N, Schlich T. "Highly qualified loser"? Harvey cushing and the Nobel Prize. J Neurosurg. 2015;122(4):976-9.

27 Philippon J, Poirier J. Joseph Babiński, a biography. New York: Oxford University Press; 2009. 
28 Gordin MD. Scientific Babel: how science was done before and after global english. 415 pp., figs., bibl., index. Chicago/London: University of Chicago Press; 2015.

29 Hansson N, Moll F, Halling T, Uvelius B. Scientific language trends among Swedish urologists and surgeons 1900-1955. World J Urol. 2019;37(5):975-82.

30 Nobel nomination for Babinski. Nobel Committee yearbook 1914. Nobel Forum, Karolinska Institute.

31 Mollaret P. Pierre Marie (1853-1940). Rev Neurol. 1939-1940;72:533-43.

32 Breathnach CS. Eduard Hitzig, neurophysiologist and psychiatrist. History Psychiat. 1992:11;329-38.

33 Lansky B. Der Beitrag Eduard Hitzigs zur zerebralen Lokalisationslehre im späten 19. Jahrhundert. Berlin: Mensch \& Buch; 2001.

34 Nobel nomination for Hitzig. Nobel Committee yearbook 1904. Nobel Forum, Karolinska Institute.

35 Hansson N, Drobietz M, Mudry A. Otorhinolaryngologists nominated for the Nobel Prize 1901-1940. Eur Arch Otorhinolaryngol. 2020;277:1255-8.
36 Hitzig II (Nobel nomination for Hitzig, Nobel Committee yearbook 1906. Nobel Forum, Karolinska Institute.

37 Liljestrand G. The prize in physiology or medicine. In: Schück H, Sohlman R, Österling A, Liljestrand G, Westgren A, Siegbahn M, editors. Nobel: the man and his prizes. New York, NY: Elsevier; 1962. p. 313.

38 Shorter E, Healy D. Shock therapy. A history of electroconvulsive treatment in mental illness. New Brunswick/NJ: Rutgers University Press; 2013.

39 Passione R. Italian psychiatry in an International Context. Ugo Cerletti and the case of electroshock. Hist Psychiat. 2004;15:83-104.

40 Nobel nomination for Cerletti. Nobel Committee yearbook 1949. Nobel Forum, Karolinska Institute.

41 Liljestrand G. The prize in physiology or medicine. In: Schück H, Sohlman R, Österling A, Liljestrand G, Westgren A, Siegbahn M, editors. Nobel: the man and his prizes. New York, NY: Elsevier; 1962. p. 322.

42 Rosenquist PB, Youssef NA, Surya S, McCall $\mathrm{WV}$. When all else fails: the use of electroconvulsive therapy for conditions other than major depressive episode. Psychiatr Clin North Am. 2018 Sep;41(3):355-71.
43 Traykov L, Boller F. Frontal lobes pathology and dementia. An appraisal of the contribution of Leonardo Bianchi. Ital J Neurol Sci. 1997 Jun;18(3):129-34.

44 Nobel nomination for Bekhterev. Nobel Committee yearbook 1914. Nobel Forum, Karolinska Institute.

45 Pfrepper R, editor. Vladimir Michajlovič Bechterev (1857-1927): neue Materialien zu Leben und Werk. Aachen: Shaker; 2007.

46 Akimenko MA. Vladimir mikhailovich bekhterev. J Hist Neurosci. 2007;16:100-9.

47 Skoromets AA, Akimenko MA. The history of neurology in St. Petersburg. J Hist Neurosci. 2017;16:90-9.

48 Nobel nomination for Jackson. Nobel Committee yearbook 1910. Nobel Forum, Karolinska Institute.

49 Hansson N, Fangerau H. Female physicians nominated for the Nobel Prize 1901-1950. Lancet. 2018;391(10126):1157-8.

50 Satzinger H. Die Geschichte der genetisch orientierten Hirnforschung von Cécile und Oskar Vogt in der Zeit von 1895 bis ca. 1927. Stuttgart: Deutscher Apotheker-Verlag; 1998. 